\title{
Empowering Academic Librarians in their Quest for Social Justice and Recognition in Academia
}

\author{
Ahmed Alwan, California State University, Northridge \\ Joy M. Doan, Northwestern University \\ Julieta Garcia, California State University, Northridge
}

Keywords: academic libraries; microaggressions; social justice

Publication Type: poster

\begin{abstract}
Academic librarians aspire to develop collegial partnerships with teaching faculty. Many academic librarians, however, have expressed frustration about maltreatment by some teaching faculty that could be construed as microaggressive. The principal investigators hypothesized that this treatment may stem from a difference in perceived status between academic librarians and teaching faculty. To test this hypothesis, the researchers distributed a survey in early 2016 to academic librarians in the United States and Canada to determine how, where, why, and when academic librarians experience status-based microaggressions when dealing with teaching faculty.

Currently, the principal investigators have analyzed and disseminated analysis of the quantitative data from the survey, however, we are now in the process of examining the qualitative data. The quantitative data indicated that status-based microaggressions are not endemic, but do exist to a level that is concerning and can lead to diminished collaborative efforts. The purpose of the current phase of the research project is to analyze the qualitative data to see if these findings are substantiated.

We believe that the qualitative data will provide us with a much richer insight into the anecdotal evidence and experiences of academic librarians and status-based microaggressions. The results of this research have the potential to greatly impact the ways in which academic librarians interact with teaching faculty. Many Library and Information Science (LIS) professionals are ill equipped to effectively deal with status based microaggressive interactions with teaching faculty and are forced to learn on the job with little to no training. This type of training would be a beneficial component of MLIS education.

In an effort to encourage student participation in this project and to provide insight into the relationship that can exist between academic librarians and teaching faculty, the principal investigators applied for a grant that would allow us to hire an MLIS graduate student to assist in the analysis of the qualitative data set. The student would be responsible for utilizing software to analyze the data sets, would have the opportunity to collaborate on any resulting publication and presentations, and would enter the scholarly conversation on a topic that is controversial within the field of Library Science.
\end{abstract}

The aim of this poster is twofold. Firstly, we hope to share the preliminary results of the 
qualitative analysis thus far. Secondly, the poster will showcase how the hiring of a graduate student serves not only to further the research on status-based microaggressions, but also as an example of how mentoring can bring new MLIS graduates into ongoing scholarly conversations within the field of LIS.

The following references were consulted in the preparation of the abstract and poster.

Alabi, J. (2015). Racial microaggressions in academic libraries: Results of a survey of minority and non-minority librarians. The Journal of Academic Librarianship, 41(1), 47-53.

Badke, W. B. (2005). Can't get no respect: Helping faculty to understand the educational power of information literacy. Reference Librarian, 43(89/90), 63-80.

Budd, J. M. (2005). The changing academic library. Chicago, IL: American Library Association.

Christiansen, L., Stombler, M., \& Thaxton, L. (2004). A report on librarian-faculty relations from a sociological perspective. The Journal of Academic Librarianship, 30(2), 116-121.

Pierce, C. (1970). Offensive mechanisms. In F.B. Barbour (Ed.), The black seventies (pp. 265182). Boston, MA: Porter Sargent Publishers.

Sue, D. W. (2010). Microaggressions and marginality: Manifestation, dynamics, and impact. Hoboken, N.J.: Wiley.

Ahmed Alwan (ahmed.alwan@csun.edu) is faculty at California State University, Northridge (CSUN) and a Research, Instruction and Outreach Librarian in the Oviatt Library. In the most recent years leading up to his appointment at CSUN, Ahmed was the Information Literacy Librarian at the American University of Sharjah in the United Arab Emirates. Ahmed has a Bachelor of Arts degree in History and Religious Studies from York University, and a Master of Information Science degree from the University of Toronto.

Joy M. Doan (joymdoan@northwestern.edu) is a Music Research and Instruction Librarian at Northwestern University. Prior to joining the library faculty at Northwestern, Joy held positions at California State University, Northridge (CSUN) as a Research, Instruction and Outreach Librarian and the University of California, Los Angeles (UCLA), where she served as the Music Inquiry and Research Librarian. Joy holds a Bachelor of Arts in English Literature and Music from the University of Michigan, an M.A. in Music History from Case Western Reserve University, and a Master of Library and Information Science degree from San Jose State University.

Julieta Garcia (julieta.garcia@csun.edu) currently works at California State University, Northridge (CSUN) as a member of the Special Collections and Archives, processing material for the International Guitar Research Archives (IGRA). She is in the process of completing her Master in Library Information Science degree at San Jose State University and received her Bachelor of Arts degree in Psychology. In an attempt to continuously develop her knowledge in the archival field, Julieta attends conferences such as Society of California Archivists and the Society of American Archivists, and is involved with community organizations like LA as Subject (LAAS) and LA Archives Collective (LAAC). 